\title{
Motorcycle Selection Decision Support System Using the Electre III Method
}

\author{
Florentina Dwi Widyastuti \\ Faculty of Science and Technology, Universitas Sanata Dharma , Indonesia
}

\begin{tabular}{|c|c|}
\hline ARTICLEINFO & ABSTRACT \\
\hline Article history: & \multirow{3}{*}{$\begin{array}{l}\text { In making a decision on the selection of a motorcycle, someone wil } \\
\text { consider various criteria to get the best decision. To simplify the } \\
\text { process, an application program for motorcycle selection decisior } \\
\text { making is made in this thesis. The application program was built by } \\
\text { applying the Electre III method which is able to solve problems with } \\
\text { many criteria. The criteria used are divided into } 2 \text { parts, namely } \\
\text { technical factors such as dimensions, front brakes, rear brakes } \\
\text { engine type, front suspension, rear suspension and cylinder volume } \\
\text { and subjective factors such as availability of spare parts, available } \\
\text { service areas, credit process, motorcycle body, motorcycle color } \\
\text { after-sales price, spare part price, purchase price, fuel consumption } \\
\text { speed and durability. The system will search for motorcycles from } \\
\text { the database whose subjective and technical factors are the same } \\
\text { as those entered by the user. Furthermore, the system will compare } \\
\text { the value of the criteria between the selected motorcycle } \\
\text { alternatives. }\end{array}$} \\
\hline $\begin{array}{l}\text { Received Jun 9, } 2021 \\
\text { Revised Jun 20, } 2021 \\
\text { Accepted Jul 08, } 2021\end{array}$ & \\
\hline $\begin{array}{r}\text { Keywords: } \\
\text { Electre method; } \\
\text { Databases; } \\
\text { Motorcycle. }\end{array}$ & \\
\hline
\end{tabular}

This is an open access article under the CC BY-NC license.

\section{Corresponding Author:}

Florentina Dwi Widyastuti,

Faculty of Science and Technology, Universitas Sanata Dharma, Indonesia

E-mail: florenrina99@gmail.com

\section{INTRODUCTION}

Life has become easier with computers. Computers can help humans in many ways, both in business, accounting, medical and other fields, which increasingly shows computers as universal tools. Humans try to computerize everything in the hope of making work easier with the automation obtained and obtaining more accountable accuracy.

One form of the computer as a tool is a computerized system to select a motorcycle. At first glance it looks so easy, but if there are enough considerations, the selection process will be complicated. There are several general criteria that are considered in choosing a motorcycle, namely funds, security, comfort, etc. It is hoped that the more parameters that are taken as reference material, the results obtained will truly represent the consumer's choice of motorcycles.

Decision is the activity of selecting an action from a set of alternatives to solve a problem (Daihani, 2001). Decision making is a management activity in the form of selecting actions from a set of alternatives that have been previously formulated to solve problems or conflicts in management (Daihani, 2001). Decision support system is a computer-based information system that is interactive, flexible, adaptable, and specifically developed to improve decision making in solving semi-structured or unstructured problems.

According to Simon (1980), decisions based on the level of regularity are subdivided into structured decisions, namely decisions related to previously known issues, with the decision- 
making process based on certain techniques and standards have been made, and unstructured decisions, namely decisions that related to new problems.

\section{METHOD}

The general design of the system is the stage to define functional requirements in preparation for the implementation design. The general flow chart of the design of this system can be seen in Figure 3.1

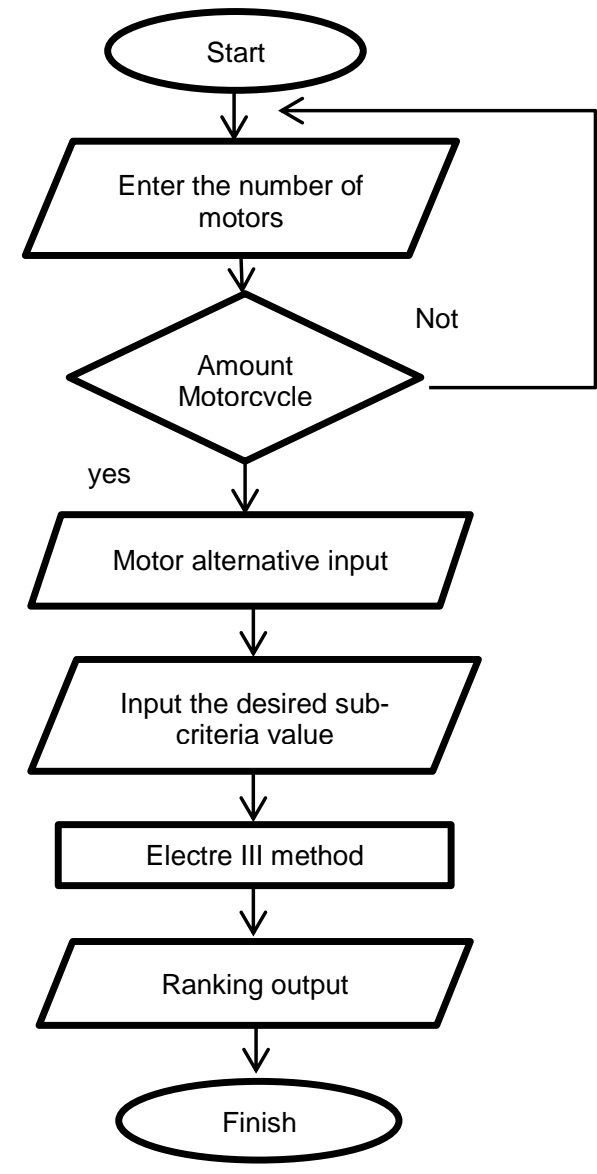

Figure 1 System Flowchart

a. Doing research with a questionnaire about some of the data that can be used as criteria in the selection of motorcycles.

b. Study of literature

1. studied the Electre III method, which is one of the methods to support decision making.

2. learn programming techniques suitable for the design and implementation of the Electre III method.

c. Designing SPPK with the Electre III method

1. Analyzing System Requirements

2. System General Design

3. Database Design

4. Interface Design

5. Process Design

d. Implementing the Electre III Method Design 


\section{RESULTS AND DISCUSSIONS}

1. Example of a Motorcycle Selection Case using the Electre III method A user wants to compare the Charisma_X125D and Jupiter_MX. Then the user will input the number of motorcycles, the name and brand of the motorcycle. After that, the user will enter the conditional value of the user. This value is the user's choice of sub-criteria. Suppose the input from the user is as shown in table 1.

Table 1.

User Input Table

\begin{tabular}{ccc}
\hline Criteria & Sub-criteria & Mark \\
\hline Safety and comfort & Availability of Spare Parts & Lots \\
Safety and comfort & Place of Service & Lots \\
Safety and comfort & Credit Process & Fast \\
Model & Motorcycle body & Small \\
Model & Motorcycle color & light \\
Financial & Purchase price & Currently \\
Financial & After Sales Price & Expensive \\
Financial & Spare Parts Price & Inexpensive \\
Reliability & Speed & Tall \\
Reliability & Fuel Consumption & Do not know \\
Reliability & Durability/life of use & Do not know \\
Specification & Dimension & Currently \\
Specification & Front Brake & Disc \\
Specification & Rear Brake & Tromol \\
\hline
\end{tabular}

After getting input from the user, the input value will be compared with the value in the database. The user also does not need to fill in all the sub-criteria values provided by the system. The system will look for which motorbike the criteria are as desired by the user. And then the system will display which motors are eligible and which are not eligible from the user. The data contained in the database for the two motors are as follows:

Table 2.

Calculation Table

\begin{tabular}{cccc}
\hline Criteria & Sub-criteria & Charisma_X125D & Jupiter_MX \\
\hline Safety and comfort & Availability of Spare Parts & Lots & Currently \\
Safety and comfort & Place of Service & Lots & Lots \\
Safety and comfort & Credit Process & Fast & Fast \\
Model & Motorcycle body & Small & Small \\
Model & Motorcycle color & light & Dark \\
Financial & Purchase price & Currently & Currently \\
Financial & Price of spare parts & inexpensive & Expensive \\
Financial & After Sales Price & Expensive & Inexpensive \\
Reliability & Fuel Consumption & economical & Currently \\
Reliability & Speed & Tall & Currently \\
Reliability & Durability/life of use & Durable & Durable \\
Specification & Dimension & Currently & Currently \\
Specification & Front Brake & Disc & Disc \\
Specification & Rear Brake & Tromol & Tromol \\
\hline
\end{tabular}

From the data in the database, it can be seen that the motorcycle that meets the requirements is Karisma_X125D. However, because the user chooses that the motor that does not meet the requirements is included in the calculation, both motors will be included in the calculation. The assessment for each sub-criteria is carried out by the admin and the Value Table for each sub-criteria can be seen in table 3 .

Table 3.

Sub-criteria Value Table

\begin{tabular}{lcl}
\hline \multicolumn{1}{c}{ Sub-criteria } & Mark & \multicolumn{1}{c}{ Description } \\
\hline Availability of spare parts & 90 & Many \\
Availability of spare parts & 75 & Currently \\
Availability of spare parts & 50 & a little \\
Availability of spare parts & 0 & Do not know \\
\hline
\end{tabular}




\begin{tabular}{lcl}
\hline \multicolumn{1}{c}{ Sub-criteria } & Mark & \multicolumn{1}{c}{ Description } \\
\hline Available service points & 85 & Many \\
Available service points & 70 & currently \\
Available service points & 45 & a little \\
Available service points & 0 & Do not know \\
Credit Process & 80 & Fast \\
Credit process & 50 & currently \\
Credit Process & 35 & difficult \\
Motorcycle body & 45 & Big \\
Motorcycle body & 75 & Small \\
Motorcycle body & 0 & Do not know \\
Motorcycle Color & 60 & Light \\
Motorcycle Color & 70 & Dark \\
Motorcycle color & 0 & Do not know \\
Purchase price & 60 & expensive \\
Purchase price & 80 & currently \\
Purchase price & 20 & inexpensive \\
Purchase price & 0 & Do not know \\
After Sales Price & 80 & Expensive/high \\
After Sales Price & 70 & currently \\
After Sales Price & 60 & inexpensive \\
After Sales Price & 0 & Do not know \\
Price of spare parts & 20 & Expensive \\
Spare Parts Price & 40 & Currently \\
Spare Parts Price & 60 & Inexpensive \\
Spare Parts Price & 0 & Do not know \\
Fuel consumption & 45 & wasteful \\
Fuel consumption & 65 & Currently \\
Fuel consumption & 85 & economical \\
\hline
\end{tabular}

Previously, the admin had determined the threshold value for each criterion. Giving this value depends on the admin's assessment. The threshold table consists of the preference threshold, indifferent threshold, veto threshold and weight. The threshold value for each criterion can be seen in table 4

Table 4.

Criteria Threshold Value Table

\begin{tabular}{lccccc}
\hline & $\begin{array}{c}\text { Safety and } \\
\text { comfort }\end{array}$ & Model & Financial & Reliability & Specification \\
\hline $\begin{array}{l}\text { Preferences } \\
\text { threshold }\end{array}$ & 50 & 50 & 50 & 50 & 50 \\
$\begin{array}{l}\text { Indifferent } \\
\text { threshold }\end{array}$ & 25 & 25 & 25 & 25 & 25 \\
$\begin{array}{l}\text { Veto threshold } \\
\text { Weight }\end{array}$ & 100 & 100 & 100 & 100 & 100 \\
\hline
\end{tabular}

2. Calculating Performance Matrix

After the input is obtained, the data is processed into a performance matrix. The performance matrix is obtained by adding up the value of each sub-criteria and then taking the average. The result of the sum is the value of each criterion and is used to form a performance matrix. Table 3.4 is the result of the performance matrix.

Table 5.

Performance Matrix Table

\begin{tabular}{cccccc}
\hline & $\begin{array}{c}\text { Safety and } \\
\text { comfort }\end{array}$ & Model & Financial & Reliability Specification \\
\hline Charisma_X125D & 240 & 135 & 160 & 255 & 430 \\
Jupiter_MX & 145 & 70 & 150 & 115 & 400 \\
\hline
\end{tabular}

3. Calculating Concordance Matrix

The results of the performance matrix are used to calculate the concordance matrix. The formula for the concordance matrix is as follows. 
$C(a, b)=\frac{1}{k} \sum_{\mathrm{j}=1}^{r} k_{\mathrm{j}} c_{\mathrm{j}}(a, b)$, where $k=\sum_{\mathrm{j}=1}^{r} k_{\mathrm{j}}$

Table 6.

Concordance Matrix Table

\begin{tabular}{ccc}
\hline & Charisma_X125D & Jupiter_MX \\
Charisma_X125D & 1.00 & 1.00 \\
Jupiter_MX & 0.36 & 1.00 \\
\hline
\end{tabular}

Calculating Positive and Negative Separation Distance, after the results of weighted normalization are obtained, the maximum and minimum values for each criterion are searched.

$$
\begin{aligned}
& \text { PIS }=A^{+}=\left\{V_{1}^{+}, V_{2}^{+} \ldots, V_{n}^{+}\right\}, \text {where: } V_{j}^{+}=\left\{\left(\operatorname{maxi}\left(V_{i j}\right) \text { if } j \in J\right) ;\left(\operatorname{mini} V_{i j} \text { if } j \in J^{\prime}\right)\right\} \\
& \text { NIS }=A^{-}=\left\{V_{1}^{-}, V_{2}^{*} \ldots, V_{n}^{-}\right\}, \text {where: } V_{j}^{-}=\left\{\left(\operatorname{mini}\left(V_{i j}\right) \text { if } j \in J\right) ;\left(\operatorname{maxi} V_{i j} \text { if } j \in J^{\prime}\right)\right\}
\end{aligned}
$$

The maximum and minimum values are to determine the positive ideal solution and the negative ideal solution. The following are the maximum and minimum results obtained from the weighted normalization table:

Table 7.

Table of Positive and Negative Ideal Solutions

\begin{tabular}{ccccc}
\hline & KK & SOUL & TANK & HAMLET \\
\hline MAX & 3.265224931 & 1.142107 & 1.7588 & 1 \\
MIN & 0.087273293 & 0.038361 & 0.19542 & 0.25 \\
\hline
\end{tabular}

Calculate the separation size. This separation measure is a measurement of the distance from an alternative to a positive ideal solution and a negative ideal solution.

Get a positive ideal solution value:

4. Creating Rankings

After obtaining the T matrix, it remains only to add up the values in each row and column for each alternative. And the value for each alternative is the result of subtraction for each row minus the column. After obtaining the results, the rows and columns with the largest results are removed. This is called descending distillation. Done until all is done for all alternative pairs. It is also calculated for the smallest subtraction value between rows and columns or it is called Ascending distillation. This is done for all alternative pairs. The end result is to combine all the results obtained from the two

Table 8.

Table of Results Ranking from high to low

\begin{tabular}{ll}
\hline Motorcycle Name & Mark \\
\hline Charisma_X125D & 3 \\
Jupiter_MX & 2 \\
\hline
\end{tabular}

Table 9.

Table of Results Ranking from low to high

\begin{tabular}{ll}
\hline Motorcycle Name & Mark \\
\hline Charisma_X125D & 0 \\
Jupiter_MX & 1 \\
\hline
\end{tabular}

Table 10.

Table of Results Ranking from low to high

\begin{tabular}{ll}
\hline Motorcycle Name & Mark \\
\hline Charisma_X125D & 4 \\
Jupiter_MX & 2 \\
\hline
\end{tabular}


From the combination table, it can be seen that the results obtained are that Karisma gets the first rank with a higher value than Jupiter_MX . Jupiter_MX is in second place. The result of implementing SPPK for Motorcycle Selection is that this system can support the motorcycle selection process and decision making. The results obtained for the admin are that the admin can update the data in the system database, which can delete, save, add motorcycle data, criteria and motorcycle brands. For users with this system can make decisions to choose a motorcycle. Users can also quickly find out the details of the selected motor data. In general, this system can simplify the process of selecting a motorcycle that works computerized to calculate and compare the criteria for the motorcycle that best fits the requirements of the user's choice.

\section{CONCLUSION}

From the Decision Support System Program for Motorcycle Selection with the Electre III Method, it can be concluded that the Electre III Method is able to overcome qualitative criteria, so as to be able to solve the problem of selecting motorcycles that have qualitative values. The application of the Electre III method in making this application program succeeded in obtaining an application program that could assist in the process of selecting a motorcycle with many criteria.

\section{References}

Buchanan, John dan Sheppard, Philip,2003. Project Rangking Using Electre III

(www.mngt.waikato.ac.nz/depts/mnss/john/electwp.pdf)

Budiharto, Widodo, S.Si. 2002. Aplikasi Database dengan SQL Server 2000 dan Visual Basic 6, Jakarta : PT. Elex Media Komputindo.

Daidani, Dadan Umar, 2001. Komputerisasi Pengambilan Keputusan. Jakarta: PT. Elek Media.

Hartono , Jogyanto.1989.Analisis dan Desain.Yogyakarta : Andi Offset.

Multi Criterion Decision Making using Electre ,2003 (www.ecolu-info.unige.ch/-haurie/ mutate/mutatefinal/lectures/lect_1_3_2/lect_1_3_2.htm).

Suryadi, Kadarsah.1989. Sistem Pendukung Keputusan Suatu Wacana Struktural Idealisasi dan Implementasi Konsep Pengambilan Keputusan.Jakarta:

PT. Remaja Rosdakarya.

TOPCU, Dr.Y.Ilker,Outranking Methods, www.llkertopcu.net

Turban, Efraim, Jay E. Aronson, Ting-Peng Liang , 2005. Decision Support Systems and Intelligent Systems (Sistem Pendukung Keputusan dan Sistem Cerdas). Yogyakarta : Penerbit Andi 